\title{
KINETIC PROPERTIES OF SUBTILISIN TYPE CARLSBERG IN THE CRYSTALLINE STATE
}

\author{
by \\ ERIK TUCHSEN \\ and \\ MARTIN OTTESEN \\ Department of Chemistry, Carlsberg Laboratory \\ Gamle Carlsberg Vej 10, DK-2500 Copenhagen, Valby
}

Keywords: Subtilisin, protein crystals, cross-linked crystals, glutaraldehyde, immobilized enzyme

Crystals of subtilisin Carlsberg were insolubilized by cross-linking with glutaraldehyde in sodium sulphate solutions at pH 5.5. Depending upon the reaction time, 3 to 6 of the 9 lysyl residues were modified while none of the other amino acids appeared to be involved. The insolubilized crystals were highly active and the kinetic constants for the hydrolysis of $N$-trans-cinnamoylimidazole and tosylarginine methyl ester were changed only moderately, suggesting the conformations of subtilisin in the crystalline and solution states to be very similar. The activity towards casein was low, indicating that this high molecular weight substrate was unable to penetrate into the interior of the crystals. Compared with the dissolved enzyme, the cross-linked crystals autolyzed at much lower rates, had increased thermal stability, were slightly more stable in acid solutions, and had unchanged stability in alkaline solutions. Although kinetic control experiments in unbuffered solutions indicated the absence of diffusional restrictions with respect to small synthetic substrates, the diffusion of hydroxyl ions into the crystal matrix was insufficient to prevent a $\mathrm{pH}$ decrease within the crystals due to the protons being released by the hydrolysis of the substrates. The addition of buffers in low concentrations essentially eliminated this $\mathrm{pH}$ difference by accelerating the transport of protons.

\section{INTRODUCTION}

Enzymes have frequently been demonstrated to be catalytically active in the crystalline state (for a review, see RupLEY (17)). However, the detailed kinetics of crystalline enzymes have been investigated only in a few cases under conditions where the influence of diffusional limitations could be excluded. VALLEE and his coworkers investigated the kinetics of carboxypeptidase A and carboxypeptidase B in the crystalline state, and observed consistently for both enzymes large decreases in $k_{\text {cat }}$ 's but only slight changes of $\mathrm{K}_{\mathrm{m}}$ 's with various substrates $(19,1)$. For carboxypeptidase A these studies were combined with studies based on spectrochemical reporter groups, and the 
results strongly suggested that the crystallization process changed the conformation of this enzyme in the region where tyrosine 248 was located. KASVINSKY and MADSEN (11) similarly observed that crystallization reduced the maximal velocities of glycogen phosphorylase a and phosphorylase $b$ from 10 to 100 -fold with little or no variations in the $\mathrm{K}_{\mathrm{m}}$ values. They emphasized that although the loss of catalytic efficiency pointed to differences in the active sites of these enzymes caused by the crystallization, another explanation might be that the crystals were restricting conformational changes that were essential parts of the catalytic cycle.

In the present report we have studied the effect of crystallization upon a proteolytic enzyme, subtilisin Carlsberg, which is known to have a three-dimensional conformation of high stability (13). Under conditions where diffusion restrictions appeared to be eliminated, crystallization influenced both the $\mathrm{k}_{\text {cat }}$ 's and $\mathrm{K}_{\mathrm{m}}$ 's of this enzyme only moderately, suggesting that the conformation in the crystalline and the dissolved states were closely similar.

\section{MATERIALS AND METHODS}

\subsection{Materials}

Subtilisin type Carlsberg was obtained from Novo Industry $\mathrm{A} / \mathrm{S}$, Copenhagen, as a lyophilized powder prepared from a dialyzed solution of crystallized enzyme. A single batch of enzyme, lot.no. 60420, was used throughout the present work and active site titrations with cinnamoyl imidazole (3) indicated contents of about $53 \%$ active enzyme. For use in cross-linking experiments, subtilisin was purified by amorphous precipitation with sodium sulphate and recrystallized twice by slow additions of saturated sodium sulphate solution at $\mathrm{pH} 5.5$ and room temperature as described previously (14). After washing three times with $15 \%(w / v)$ sodium sulphate solution, the crystals appeared as slender needles, $50-200 \mu \mathrm{m}$ in length and below $5 \mu \mathrm{m}$ in the two other dimensions.
Tosyl-L-arginine methyl ester (TAME)* was obtained from Sigma Chemical Co., St. Louis, USA. $N$-trans-cinnamoylimidazole $(\mathrm{NtCl})$ was a pure grade from Fluka, Switzerland. This compound was recrystallized five times from dry cyclohexane before use (M.P. $134^{\circ} \mathrm{C}, \lambda_{\max } 307$ $\left.\mathrm{nm}, \varepsilon_{\max } 21.7 \times 10^{3} \mathrm{M}^{-1} \mathrm{~cm}^{-1}\right)$. Glutaraldehyde was obtained as $25 \%(\mathrm{w} / \mathrm{v})$ aqueous solution from Fluka and used without further purification. Other reagents were of analytical grade.

\subsection{Methods}

Cross-linked crystalline subtilisin Carlsberg was prepared from subtilisin crystals in sodium sulphate by treatment with approximately $1 \%$ $(\mathrm{w} / \mathrm{v})$ glutaraldehyde at $\mathrm{pH} 5.5$ by a modification of the method used by QuIOCHO and RICHARDS (16). In a typical preparation $19 \mathrm{ml}$ of crystal suspension containing $400 \mathrm{mg}$ enzyme in $15 \%$ sodium sulphate was placed in a $\mathrm{pH}$-stat vessel with slow stirring at room temperature. The $\mathrm{pH}$ was maintained at 5.5 with $0.1 \mathrm{M}$-sodium hydroxide in the burette, a $3 \mathrm{ml}$ aliquot was removed, and the reaction was started by slow addition of $0.75 \mathrm{ml}$ of $25 \%(\mathrm{w} / \mathrm{v})$ glutaraldehyde solution. At various time intervals $3 \mathrm{ml}$ aliquots of the crystal suspension were removed, each aliquot was diluted five times with $15 \%$ sodium sulphate solution to stop further reaction, and the glutaraldehyde treated crystals were isolated by centrifugation as soon as possible and washed twice with $10 \mathrm{ml}$ of $15 \%$ sodium sulphate solution. Finally, the crystals were suspended and stored in $3 \mathrm{ml}$ of the sodium sulphate solution to which had been added a few drops of toluene.

Before use, the crystals of the stock suspensions were washed several times with a large excess of water in small centrifuge tubes. A set of Carlsberg pipettes with extra wide tips were used for reproducible pipettings of the crystal suspensions in volumes from $10-100 \mu$ l.

Enzymatic activities of the insolubilized crystals were determined from the hydrolysis rate of $5 \mathrm{mM}$-TAME in $0.1 \mathrm{M}-\mathrm{KCl}$ at $\mathrm{pH} 8$ and $30^{\circ} \mathrm{C}$. The hydrolysis rates were followed by

*) Abbreviations used: TAME, Tosyl-L-arginine methylester; $\mathrm{NtCI}, N$-trans-cinnamoylimidazolt. 
means of a Radiometer $\mathrm{pH}$-stat composed of pH-meter Model PHM 64, titrator Model TTT 60, autoburette Model ABU 13, recorder Model REC 61 with pen drive Model REA 300. The thermostated reaction vessel with magnetic stirring contained $2 \mathrm{ml}$ reaction mixture and 0.100 or $0.025 \mathrm{M}$-sodium hydroxide, free of $\mathrm{CO}_{2}$, was used as titrant. A slow stream of nitrogen was passed through the closed reaction vessel to prevent any $\mathrm{CO}_{2}$-uptake from the atmosphere. Stock solutions of the substrate were stored in tightly sealed vessels at $5^{\circ} \mathrm{C}$ or in the freezer.

Kinetic experiments were performed by a similar procedure using 1-40 mM-TAME as substrate and the crystal suspension which had been reacted $45 \mathrm{~min}$ with glutaraldehyde normally served as the enzyme source. Ten minutes before use, substrate solutions were transferred to a $30^{\circ} \mathrm{C}$ thermostated bath. For the kinetic experiments $10 \mu$ of diluted crystal suspension containing about $16 \mu \mathrm{g}$ of protein were used. Separate control experiments established that the measured reaction velocities were proportional to the amount of enzyme added over the range from 2 to $50 \mu \mathrm{g}$ of protein/ $\mathrm{ml}$.

Similar preparations of cross-linked crystals were used for the kinetic experiments with $\mathrm{NtCI}$. The hydrolysis was followed by the changes in UV absorption using a Cary Model 118 spectrophotometer. To $3.00 \mathrm{ml}$ reaction mixture containing $0.1 \mathrm{M}$-phosphate buffer, $\mathrm{pH}$ 7.0 , the desired concentration of substrate was added as a solution in acetonitrile. Additional acetonitrile was added to the vessels to make the total concentration of this compound $0.66 \%$ (w/ v) in all experiments. The spontaneous autolysis of the $\mathrm{NtCl}$ was followed during few minutes at $325 \mathrm{~nm}$ before $40 \mu \mathrm{l}$ of the washed, cross-linked crystal suspension (containing about $60 \mu \mathrm{g}$ of protein) was added. An effective, mechanical stirrer (2) was placed in the top of the cuvette, and the hydrolysis of the substrate was followed for periods from 4 to $10 \mathrm{~min}$, as required to obtain precise determinations of initial rates. The concentration of crystals suspended in the solution during these measurements resulted in a dispersion of radiation corresponding to about 0.2 absorbance units, establised previous- ly to be within the limits which did not affect the rate measurements (2).

The protein content of the crystals and the extent of cross-linking were determined by amino acid analysis. Samples of crystals containing about $1 \mathrm{mg}$ of protein were hydrolyzed with $1 \mathrm{ml} 6 \mathrm{M}-\mathrm{HCl}$ in evacuated tubes for 24 hours at $110^{\circ} \mathrm{C}$ and analysed in a Durrum Model D-500 amino acid analyzer.

\section{RESULTS}

\subsection{The cross-linking reaction}

Treatment of crystals of subtilisin Carlsberg with glutaraldehyde as described in Section 2.2 caused no visible change in the appearance of the crystal suspensions other than the development of a slight yellow colour which became

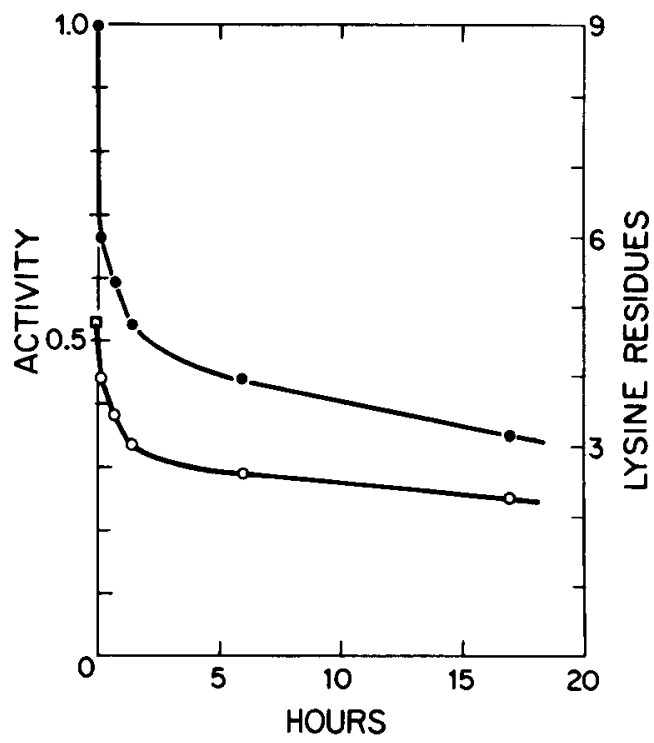

Figure 1. Modification of lysine content (--) and enzymatic activity (-O-) by treatment of subtilisin crystals with $1 \%$ glutaraldehyde in $15 \%$ sodium sulphate containing $0.1 \mathrm{M}$-sodium acetate $\mathrm{pH}$ 5.5. Content of umodified lysine residues (right ordinate) was calculated from amino acid analysis and based on the value of 41 Ala residues per mole. Activities were assayed in the $\mathrm{pH}$-stat at $\mathrm{pH} 8$ and normalized with respect to the activity of dissolved enzyme. The reaction mixture contained $5 \mathrm{mM}-\mathrm{TAME}, 0.1 \mathrm{M}-\mathrm{KCl}$ and 6 $\mu \mathrm{g}$ subtilisin crystals per $\mathrm{ml}$. The value indicated by $\square$ on the left ordinate axis represent the activity of unmodified crystals calculated as indicated in Section 3.1 . 
more intense with increasing time of exposure to the reagent. In the polarizing microscope the birefringence of cross-linked crystals was indistinguishable from the birefringence of unmodified crystals, indicating that cross-linking had not denatured the enzyme. Amorphous material was detected only in samples which had been treated with glutaraldehyde for 17 hours. Both the cross-linked and the unmodified crystals exhibited great mechanical strenght, i.e. neither were disrupted by treatment in a Potter-Elvehjem homogenizer or an ultrasonic cleaning bath.

The extent of the cross-linking reaction with glutaraldehyde was followed by means of amino acid analysis. As shown in Fig. 1 approximately three lysyl residues were modified during the first $10 \mathrm{~min}$ of the reaction, and the next three residues were modified during the subsequent 17 hours. The remaining three lysines appeared to be unreactive. The amino acid analysis did not indicate changes in the contents of any other amino acid. The decrease in enzymatic activity followed the modification of lysyl residues. After the rapid initial loss of three lysyl residues, the apparent activity of the crosslinked crystals had decreased to slightly below half of the activity of the dissolved enzyme as determined by active site titrations. During the subsequent slow reaction the activity decreased further to near $25 \%$ of the activity of the dissolved enzyme.

Attempts were made to distinguish between the activity losses arising from the chemical modifications and those due to the transfer from dissolved to the crystalline state. When the cross-linked crystals were transferred from $0.1 \mathrm{M}-\mathrm{KCl}$ to $15 \%$ sodium sulphate at $\mathrm{pH} 8$, the apparent activity increased by about $13 \%$. In this solvent the crystals of the unmodified enzyme were also stable, and it was demonstrated that less than $0.1 \%$ of the measured activity was due to the small amount of enzyme in the solution under equilibrium conditions. Assuming the change of solvent from $\mathrm{KCl}$ to sodium sulphate solution to affect the crystals of unmodified and cross-linked enzyme to the same extent, it could be estimated from the activity of the unmodified crystals in the sodium sulphate solution that these crystals in $0.1 \mathrm{M}-\mathrm{KCl}$ would have a theoretical activity corresponding to $50-60 \%$ of the activity of the dissolved enzyme. The activity losses due to the cross-linking procedure were thus within a range from 15 to $50 \%$ of the activity of unmodified crystalline enzyme.

\subsection{Stability properties}

The cross-linked crystals which had been reacted with glutaraldehyde from 0.1 to $6 \mathrm{hrs}$ retained full activity after several months of storage at $4^{\circ} \mathrm{C}$ as suspensions in acetate buffer, $\mathrm{pH}$ 5.5. Control experiments with the $\mathrm{pH}$-stat failed to demonstrate any activity in the mother liquor, even when experimental conditions sensitive to $0.01 \%$ of the total activity in the suspensions were used. The cross-linked crystals were also highly stable towards the

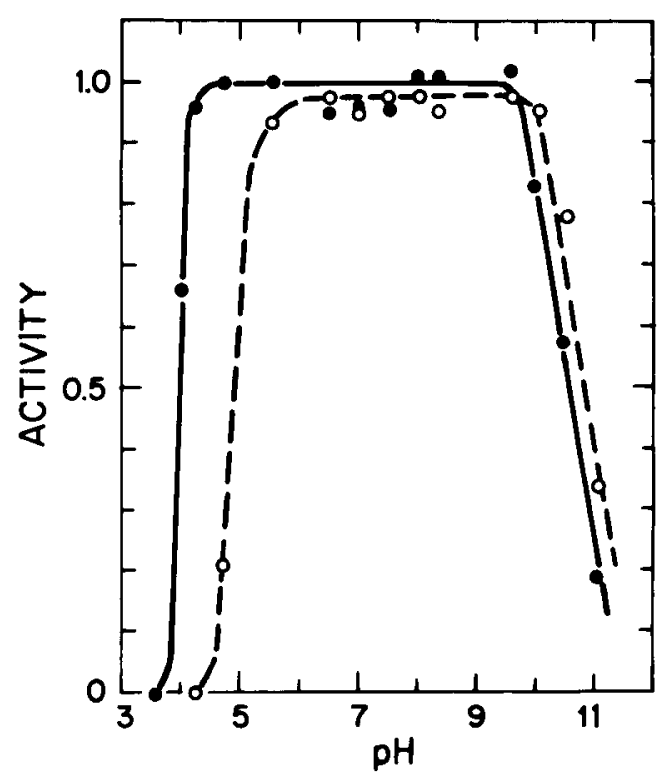

Figure 2. Stability of cross-linked subtilisin crystals (- - ) and dissolved enzyme (--O--) at various $\mathrm{pH}$ values. Aliquots of $0.5 \mathrm{ml}$ containing $70 \mu \mathrm{g}$ crystals or $400 \mu \mathrm{g}$ dissolved enzyme were incubated in the appropriate buffers for $18 \mathrm{~h}$ at $30^{\circ} \mathrm{C}$. The remaining activities were measured with $5 \mathrm{mM}-\mathrm{TAME}$ at $\mathrm{pH} 8$. The buffers used were $0.2 \mathrm{M}$-acetate at $\mathrm{pH} 4-4.5,0.1$ $\mathrm{M}$-phosphate at $\mathrm{pH} \mathrm{6-8.5}$ and $0.1 \mathrm{M}$ tetraborate at $\mathrm{pH}$ 9-11. Due to the pronounced influence of buffers on the activities of the crystals, initial values for the activities were determined in the presence of the buffer salts. 
effects of organic solvents. After 24 hours of standing in dry acetonitrile or ethylene glycol dimethyl ether only slight activity losses were observed. After evaporating acetonitrile and suspending the dried crystals in water the enzymatic activity was regained.

\subsection{1.pH-stability}

The stability of crystals which had been cross-linked by 45 minutes of reaction was investigated at various $\mathrm{pH}$-values with the results shown in Fig. 2. In the acid range near $\mathrm{pH} 4$ the crystalline enzyme was approximately 10 fold more stable towards hydrogen ions than the dissolved enzyme. In contrast, in the alkaline range their stabilities were quite similar. In the intermediate range from $\mathrm{pH} 6$ to $\mathrm{pH} 10$ the concentration of buffer salts influenced the apparent activities measured with the crystals in $\mathrm{pH}$ stat experiments, as discussed in Section 3.3. The results in Fig. 2 have been corrected for variations due to this effect.

\subsubsection{Autodigestion}

The autolysis rates of the cross-linked crystals were much lower than those of the dissolved enzyme as shown in Fig. 3. At pH 8 and $30^{\circ} \mathrm{C}$ nearly half of the dissolved enzyme had digested itself to small peptide fragments within 20 hours, while only about $0.8 \%$ of the crystalline enzyme was degraded under the same conditions. A crude comparison of the initial autolysis rates suggested the crystals to be approximately 300 fold more stable than the dissolved enzyme.

Attempts to measure autolysis rates from the uptake of base during $\mathrm{pH}$-stat experiments failed due to a relatively slow consumption of base which was larger than that originating from the peptide bonds being split. Short exposure of the crystals to higher or lower $\mathrm{pH}$ values had only small effects on the slow base uptake which presumably originated from some byproducts of the reaction of glutaraldehyde with the protein. Similar effects were noted by BLAUER et al. (4) from the interaction between glutaraldehyde and collagen.

\subsubsection{Thermal stability}

At higher temperatures the cross-linked

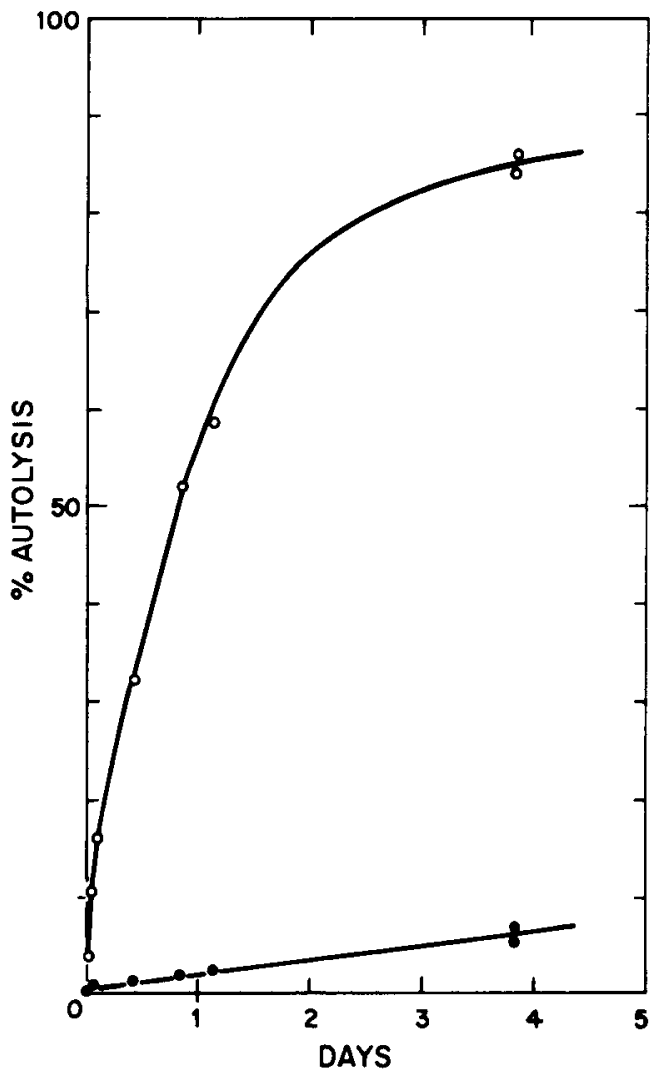

Figure 3. Formation of autolysis peptides from crosslinked subtilisin crystals (- - ) and from dissolved enzyme (- - S ). Suspensions containing $5 \mathrm{mg}$ enzyme crystals or solutions containing $20 \mathrm{mg}$ dissolved enzyme, previously purified by amorphous precipitation two times with sodium sulphate, were incubated in $2 \mathrm{ml} 0.05 \mathrm{M}$-tetraborate buffer, $\mathrm{pH} 8$, at $30^{\circ} \mathrm{C}$. At appropriate time intervals $200 \mu \mathrm{l}$ aliquots were removed and precipitated by addition of an equal volume of $20 \%$ trichloroacetic acid. Aliquots of the supernatants were submitted to amino acid analysis in order to estimate the percentage of autolysis. The amino acid composition of the autolysis peptides were found to be identical with the composition of the undegraded enzyme.

enzyme was more stable than the dissolved enzyme. As seen from Fig. 4 the dissolved enzyme lost half of its activity after approx. 1.5 hours of incubation at $55^{\circ} \mathrm{C}$ while the activity of the crystals remained unchanged even after 20 hours of incubation. At $70^{\circ} \mathrm{C}$ the dissolved enzyme lost half of its activity within less than one minute, while more than one hour passed 


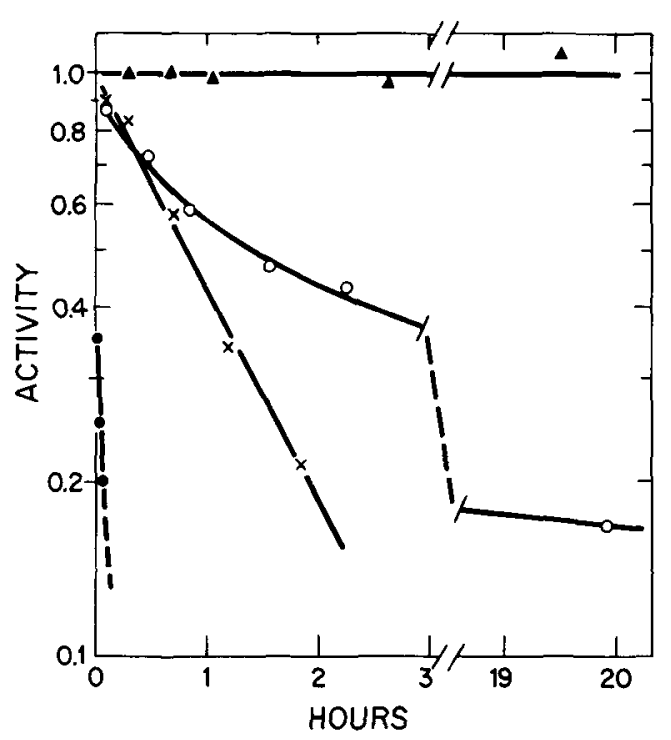

Figure 4. Thermostability of cross-linked crystals at $55^{\circ} \mathrm{C} \mathrm{(-}-$ ) and $70^{\circ} \mathrm{C}(-\mathrm{x}-\mathrm{C})$ and of dissolved enzyme at $55^{\circ} \mathrm{C}$ ( - - - $)$ and $70^{\circ} \mathrm{C} \mathrm{(—-} \mathrm{-}$ One $\mathrm{ml}$ crystal suspension or subtilisin solution (previously purified by gel filtration on a Sephadex G15 column) containing approx. $1 \mathrm{mg}$ protein in $0.1 \mathrm{M}$ acetate, $\mathrm{pH} 5.66$, were heated in small test tubes closed with parafilm. The residual activities were assayed in 30 or $50 \mu \mathrm{l}$ aliquots using $5 \mathrm{mM}$-TAME at $\mathrm{pH} 8$ and $30^{\circ} \mathrm{C}$.

before the activity of the enzyme crystals had decreased to this level. Other experiments (M.Ottesen unpublished observations) have indicated that the inactivation of enzymatically active subtilisin Carlsberg which occurs at about $55-60^{\circ} \mathrm{C}$ probably is caused by an extensive autolysis at this temperature. In constrast, diisopropyl fluorophosphonate inhibited subtilisin which autolyzes only to a minor extent retains its three-dimensional structure at considerably higher temperatures, up to 70 $75^{\circ} \mathrm{C}$. Thus, the thermal stability of the crosslinked enzyme increases to the limits set by the denaturation properties of the enzyme itself. Consistent with this explanation, the logarithmic plot of the inactivation curve in Fig. 4 is linear for the crystalline enzyme at $70^{\circ} \mathrm{C}$, as expected for a first order reaction, while that for the soluble enzyme at $55^{\circ} \mathrm{C}$ deflects in the direction expected for an enzyme inactivating itself during the time of the experiment.

\subsection{Kinetic properties}

\subsubsection{The hydrolysis of cinnamoyl imidazole}

$\mathrm{NtCI}$ was originally proposed by BENDER et al. (3) as a convenient reagent for active site titrations of various serine proteases at $\mathrm{pH} 4.5$ where the cinnamoyl enzymes were hydrolyzed only slowly. At higher $\mathrm{pH}$ this reagent may be used as a chromogenic substrate.

The initial rates of the splitting of $\mathrm{NtCl}$ by dissolved and crystalline subtilisin Carlsberg with varying degrees of cross-linking were measured at $\mathrm{pH} 7$ with substrate concentrations

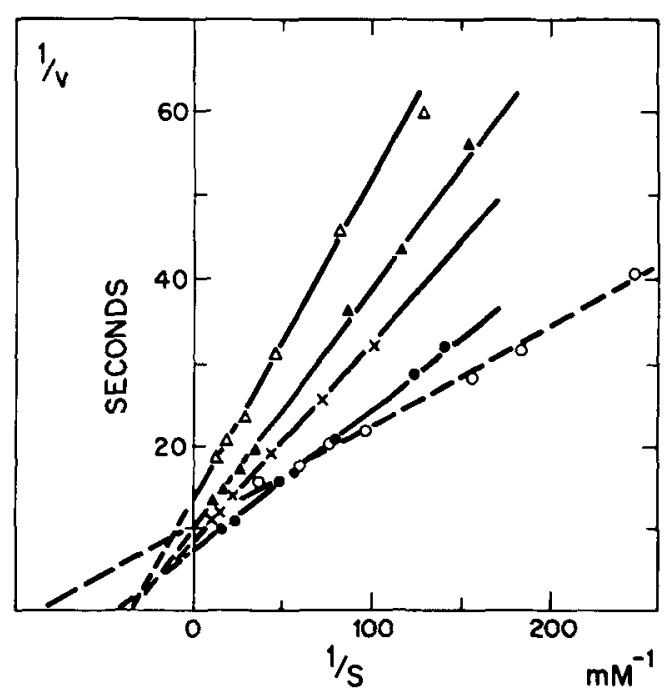

Figure 5. Lineweaver-Burk plots for the hydrolysis of $\mathrm{NtCl}$ by crystals of subtilisin with different extent of cross-linking. The hydrolysis was followed at $\mathrm{pH} 7$ and $30^{\circ} \mathrm{C}$, using $50 \mu \mathrm{g}$ subtilisin crystals in $3.1 \mathrm{ml}$ reaction mixture, from the change in UV-adsorption at 310 or $325 \mathrm{~nm}$ ( $\varepsilon=23.6$ and $17.1 \mathrm{~cm}^{2} / \mathrm{ml}$, respectively). The symbols $\bullet, x, \Delta$ and $\Delta$ refer to crystals with $3.0,3.6,4.3$ and 5.6 lysine residues modified, respectively. The curve for the dissolved enzyme (- O--) was determined under identical conditions, using reaction mixtures containing $55 \mu \mathrm{g}$ of active enzyme (as estimated from active site titrations) and following the hydrolysis at $340 \mathrm{~nm}\left(\varepsilon=6.3 \mathrm{~cm}^{2} / \mathrm{mol}\right)$. The reaction rates were estimated per mole of enzyme, with no corrections for the possible presence of inactive protein in the crystals. 
Table I

Kinetic constants for hydrolysis of $\mathrm{N}$-trans-cinnamoylimidazol by subtilisin Carlsberg.

\begin{tabular}{l|c|c|c|c}
\hline & $\begin{array}{c}\text { Lysine redidues } \\
\text { modified }\end{array}$ & $\begin{array}{c}\mathrm{K}_{\mathrm{m}} \\
\mathrm{mM}\end{array}$ & $\begin{array}{c}\mathrm{k}_{\text {cat }} \\
\mathrm{sec}^{-1}\end{array}$ & $\mathrm{k}_{\text {cat }} / \mathrm{K}_{\mathrm{m}}$ \\
\hline dissolved enzyme & 0 & 0.011 & 0.094 & 8.5 \\
crossed-linked crystals & 3.0 & 0.023 & 0.135 & 5.9 \\
crossed-linked crystals & 3.6 & 0.027 & 0.113 & 4.2 \\
crossed-linked crystals & 4.0 & 0.029 & 0.104 & 3.6 \\
crossed-linked crystals & 4.3 & 0.036 & 0.117 & 3.3 \\
crossed-linked crystals & 5.6 & 0.028 & 0.077 & 2.8 \\
\hline
\end{tabular}

The experimental conditions were identical with those described in the legend of Fig. 5.

varying from 5 to $100 \mu \mathrm{M}$. As shown in Fig. 5 reciprocal plots of the data fitted straight lines for the enzyme in both states. The kinetic constants for the various enzyme preparations (Table I) indicate that the $\mathrm{K}_{\mathrm{m}}$-values for the crystals were about two to three fold higher than for the dissolved enzyme. The $\mathrm{k}_{\text {cat }}$-values varied only slightly from those for the dissolved enzyme and with a tendency for the crystals with low degree of cross-linking to show the highest $\mathrm{k}_{\text {cat }}$.

It has been demonstrated frequently that diffusional restrictions may interfere with the function of insolubilized enzymes and cause deviations from simple Michaelis-MENTEN kinetics $(6,12)$. These deviations arise when diffusion of substrate into the catalytically active particles is insufficient to keep the concentration of substrate and reaction product at the same levels in the center of the particles as in the periphery. Such concentration differences will naturally cause larger variations between the reaction rates in the center and the periphery of the particles when the substrate concentrations being used are below or near the $\mathrm{K}_{\mathrm{m}}$-values, than when the substrate concentrations are far above the $\mathrm{K}_{\mathrm{m}}$-values. Consequently, the diffusion restrictions will be reflected in LINEWEAVER-BURK plots as deviations from linear relationships. However, as pointed out by HORVATH and ENGASSER (9), the HOFSTEE plots where $v / S$ is plotted against $\mathrm{v}$, are even more sensitive indices of diffusion restrictions. Replotting the kinetic data for a single of the preparations used in Fig. 5 into a normalized HOFSTEE plot (Fig. 6) gave 12 points which could be fitted to a straight line over the 100 -fold variation in substrate concentrations. $\mathrm{K}_{\mathrm{m}}$ was calculated to be $26.1 \pm 0.8 \mu \mathrm{M}$ using the computer program HYPER described by Cleland (5). The linearity was tested by

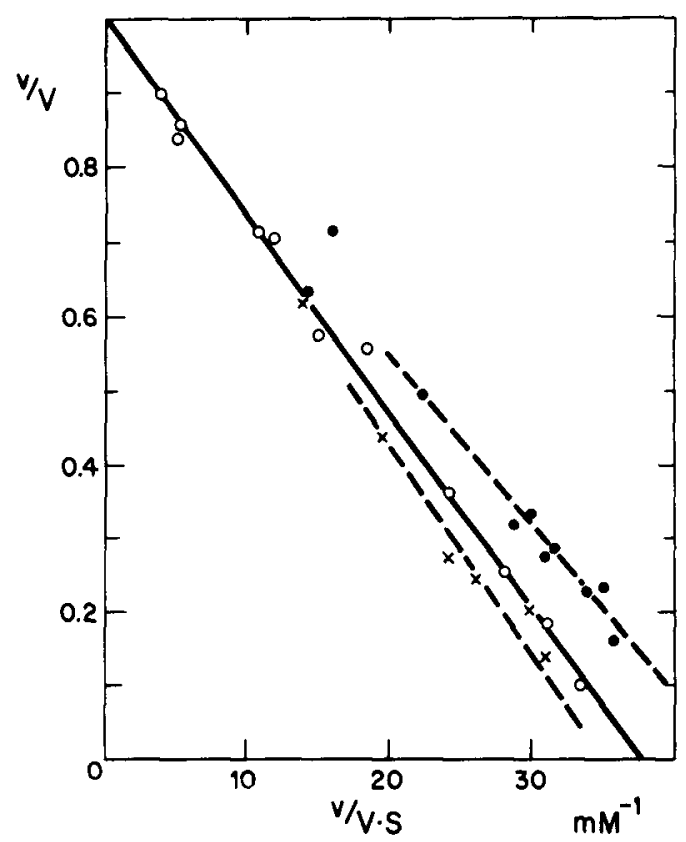

Figure 6. Normalized Hofstee plots of $\mathrm{v} / \mathrm{V}$ against $\mathrm{v} / \mathrm{V} \cdot \mathrm{S}$ for hydrolysis of $\mathrm{NtCl}$ by cross-linked subtilisin crystals. The experimental conditions were identical with those used for Fig. 5. The crystal preparation had 3.6 lysine residues modified. The full line refer to experiments with unfractionated crystal mixture while the broken lines refer to subfractions containing the larger (-_-_-) or the smaller (----x---) crystals, respectively, prepared as described in Section 3.3.1. 
omitting the five upper or the five lower concentrations and recalculating the $\mathrm{K}_{\mathrm{m}}$ 's. The results, 27.4 and $26.5 \mu \mathrm{M}$, respectively, did not differ significantly from the value when all points were included, indicating complete linearity within the limits of error.

Diffusion restrictions can also be revealed by experiments which change concentration gradients, if any are present, from the outside to the center of the particles. The simplest method of making such a change is to fractionate the crystals of the original suspension into thinner and thicker crystals by differential centrifugation. When this was done, a heavy fraction was obtained after centrifugation at $50 \mathrm{~g}$ for one minute which contained crystals of $2-5 \mu \mathrm{m}$ thickness in the smallest dimension. Crystals, less than $1 \mu \mathrm{m}$ thick in the smallest dimension, were found in a light fraction which remained suspended after $2 \mathrm{~min}$ at $200 \mathrm{~g}$. In the HOFSTEE plots (Fig. 6) the slopes indicate $\mathrm{K}_{\mathrm{m}}$-values of $22.1 \pm 2.1 \mu \mathrm{M}$ for the thick crystals and $28.5 \pm$ $2.2 \mu \mathrm{M}$ for the thinner ones, respectively. This difference is hardly significant and in any case it is in the direction opposite to that which would be expected if it originated from diffusional restrictions for the substrate.

Another method which can be used to decrease the concentration gradient from the outside to the center of the particles is to decrease the number of active sites in the insolubilized enzyme particles by partial inactivation. If diffusion restrictions are present this test should change the slopes of the HoFsteE plots leading to decreases of the observed $\mathrm{K}_{\mathrm{m}}$ values. We employed this method by exposing a preparation of cross-linked crystals to phenylmethylsulfonyl fluoride in low concentrations with partial inactivation of the enzyme occurring over a period of several minutes. Due to slowness of the reaction we assumed that the reagent at all times was distributed uniformly within the crystal, and consequently that the inactivation of active sites was distributed uniformly also. The kinetic plot obtained with the inhibited crystals was linear within the precision of the method, and the $K_{m}$ value of $37 \mu \mathrm{M}$ calculated was within the range obtained with uninhibited crystals.

Since none of the three tests demonstrated any diffusional restrictions for the $\mathrm{NtCl}$ substrate, the crystals we had prepared were sufficiently thin to preclude this source of possible error. Hence, it is permissible to compare the kinetic constants for dissolved and crystalline enzyme directly as in Table I.

\subsubsection{The hydrolysis of TAME}

TAME is a convenient substrate for subtilisin Carlsberg since it can be used at $\mathrm{pH} 8$, near the optimum for this enzyme and has a turnover

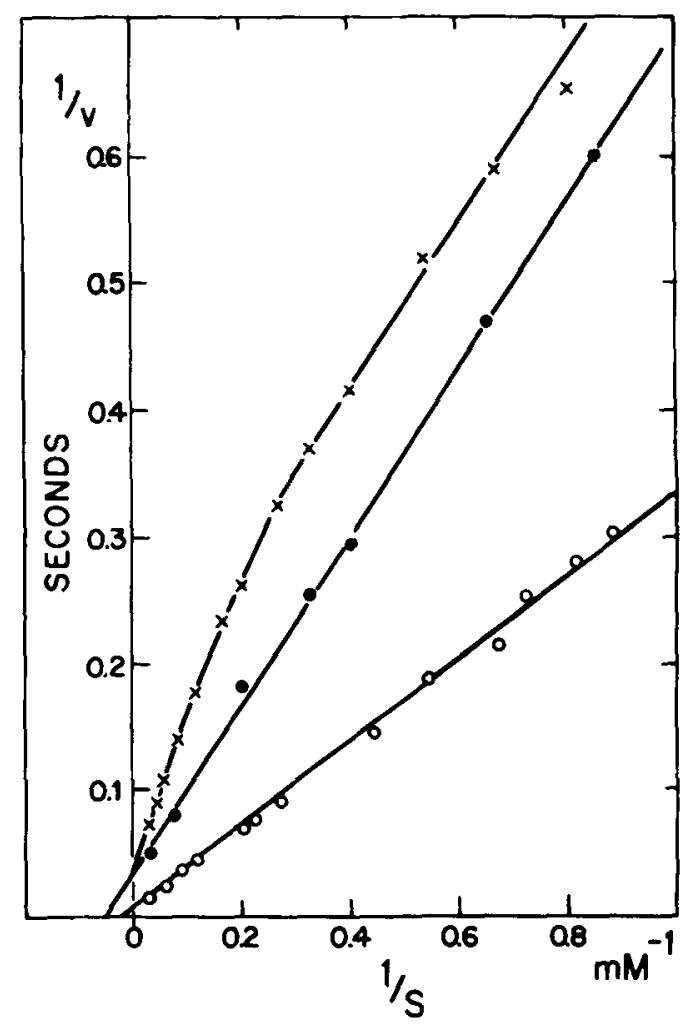

Figure 7. Lineweaver-Burk plots for the hydrolysis of TAME with cross-linked crystals (- $-\mathbf{x}-$ ) and dissolved enzyme (-O-) at pH 8 and $30^{\circ} \mathrm{C}$. The unbuffered reaction mixtures in the $\mathrm{pH}$-stat assays contained $0.1 \mathrm{M}$-potassium chloride and $6 \mu \mathrm{g} / \mathrm{ml}$ of crystals or $2 \mu \mathrm{g} / \mathrm{ml}$ of dissolved enzyme. The enzyme concentrations were calculated from amino acid analyses for the enzyme crystals and from active site titrations for the dissolved enzyme. The straight line (- - ) was obtained with crystals in $\mathrm{pH}$-stat experiments with added buffer. For reasons explained in the legend of Fig. 9 the buffer used was a mixture of $5 \mathrm{~mm}$-phosphate, $4 \mathrm{~mm}$-pyrophosphate and $5 \mathrm{~mm}$-tetraborate with a total buffer capacity of 4 $\mathrm{mM}$. 
number about three orders of magnitude higher than NtCI at pH 7. As seen in Fig. 7, the dissolved enzyme followed normal MiCHAELISMENTEN kinetics while those of cross-linked crystals in unbuffered $\mathrm{pH}$-stat experiments are biphasic with slower rates of hydrolysis of TAME than those of the soluble enzyme. The curvature was of the type normally interpreted to signify substrate activation (18).

To eliminate the possibility that this unexpected activation originated from the introduction of cross-links in the crystal, the kinetic experiments were repeated in $15 \%(\mathrm{w} / \mathrm{v})$ sodium sulphate solution where unmodified crystals were also stable. As Fig. 8 demonstrates, cross-linking could not be responsible for the biphasic characteristics of

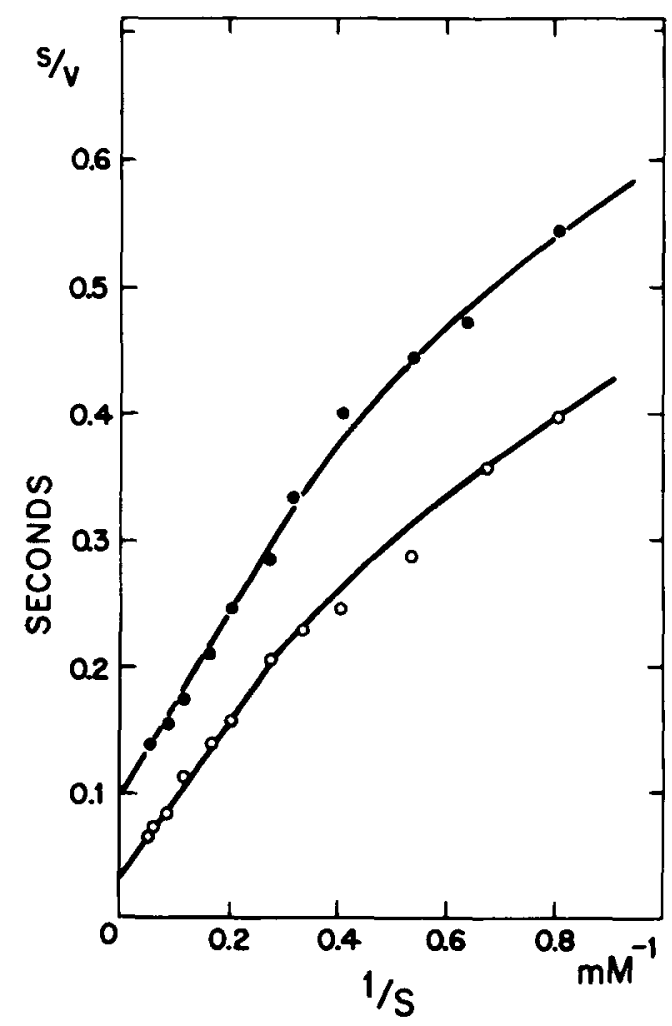

Figure 8. Lineweaver-Burk plots for the hydrolysis of TAME in unbuffered $\mathrm{pH}$-stat experiments by crosslinked (- - ) and unmodified ( - - - ) subtilisin crystals in $15 \%$ sodium sulphate solutions at $\mathrm{pH} 8$ and $30^{\circ} \mathrm{C}$. The reaction mixtures contained $6 \mu \mathrm{g} /$ $\mathrm{ml}$ of crystals which for the upper curve had been reacted with glutaraldehyde to the extent of 4.3 lysine residues modified per mol of enzyme. the curves, since these were observed with both the cross-linked and the unmodified crystals. The persistence of the biphasic shape at these high salt concentrations (ionic strength 6.0), where electrostatic interactions were drastically decreased, also excluded the possibility that the curvature might result from electrostatic interactions between charged groups in the crystal matrix and charged groups of the substrate molecules.

Determinations of the $\mathrm{pH}$ optima for the cross-linked crystal preparations indicated them to be about $\mathrm{pH} 9.3$, i.e. one $\mathrm{pH}$ unit higher than for the soluble enzyme, suggesting a plausible explanation of the biphasic curvatures (Fig 9). Further, the $\mathrm{pH}$ profile for the crystalline enzyme was also noticed to be abnormal, with a broad plateau from $\mathrm{pH} 6$ to 8 ,

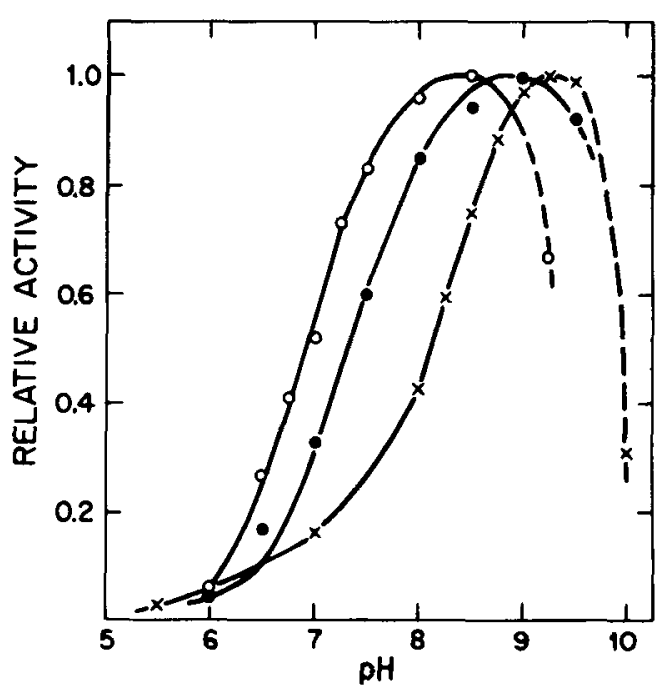

Figure 9. $\mathrm{pH}$ profiles for the hydrolysis of TAME in unbuffered $\mathrm{pH}$-stat assays with crystalline (- $-\mathrm{x}-$ ) and dissolved subtilisin ( $-\mathrm{O}-$ ). Two milliliters of reaction mixture contained 5 to $12 \mu \mathrm{g}$ enzyme in 5 mM-TAME, 0.1 M-potassium chloride. The curve $(-\ldots \ldots)$ represent analogous $\mathrm{pH}$-stat experiments with the enzyme crystals in a buffered solution with addition of $5 \mathrm{~mm}$-phosphate, $4 \mathrm{~mm}$-pyrophosphate and $5 \mathrm{~mm}$-tetraborate. This combination of buffer salts was used because it had almost constant buffer capacity, approx. $4 \mathrm{~mm}$ in the $\mathrm{pH}$ interval from 7 to 9 . Buffer capacities (BC) were calculated from the formulae $B C=2.303 \Sigma_{i} C_{i} \times K_{A i} \times\left[H^{+}\right] /\left(K_{A i}+\left[H^{+}\right]\right)^{2}$ were $C_{i}$ is the buffer concentration and $K_{A i}$ its dissociation constant. 
and a slope steeper than normal between $\mathrm{pH} 8$ and 9. This shape was strongly reminiscent of the type of $\mathrm{pH}$ profile described in a theoretical paper by ENGASSER and HOVARTH to originate from diffusional restrictions to proton movements within immobilized enzyme particles (7). These authors also pointed out that abnormalities of this category could be eliminated by increasing the buffer capacity of the reaction mixture, thus facilitating proton transport. The $\mathrm{pH}$-stat method, as used in the present report to measure the splitting of TAME (see Section 2.2), had very low buffering capacity in the reaction medium, and this permitted a test of the hypothesis of ENGASSER and HOVARTH simply by adding extraneous buffer. As demonstrated in Fig. 10, the reaction rates increased with increasing buffer concentrations to reach a plateau approx. $80 \%$ above the original rate. With Tris buffer this plateau was reached at a buffer capacity about $2 \mathrm{mM}$ while a mixed buffer with phosphate, pyrophosphate and tetraborate required a buffering capacity of about $10 \mathrm{mM}$ to reach similar values, indicating the buffer salts to have specific effects on proton transports. When the mixed buffer was added to the reaction mixture of $\mathrm{pH}$-stat experiments in a concentration giving a buffering capacity of $4 \mathrm{~mm}$ all kinetic abnormalities disappeared and the Lineweaver-Burk plots became linear (Fig. 7). At the same time the $\mathrm{pH}$ profiles moved closer to normal values (Fig. 9).

The kinetic constants for the cleavage of TAME listed in Table I were obtained from experiments in buffered solutions. It is seen that at $\mathrm{pH} 9.3$ the dissolved and the crystalline

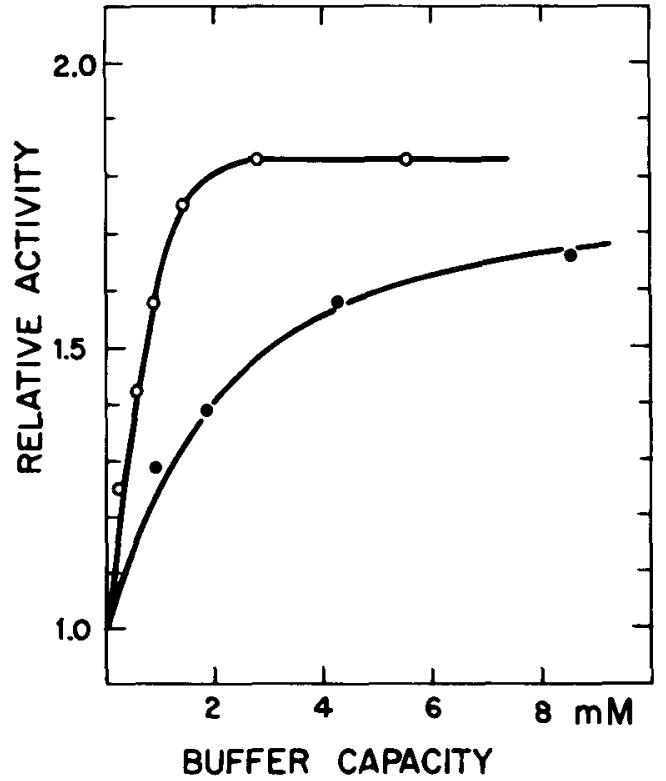

Figure 10. The influence of buffer capacity on the relative rates of TAME hydrolysis. $2 \mathrm{ml}$ of reaction mixture contained $0.1 \mathrm{M}-\mathrm{KCl}, 5$ or $10 \mu \mathrm{g}$ cross-linked crystals, $5 \mathrm{~mm}$ TAME plus $0-100 \mu \mathrm{l} 200 \mathrm{~mm}$ Tris (_- _ $)$ or $0-200 \mu \mathrm{l}$ of a buffer mixture containing $100 \mathrm{~mm}$ phosphate, $80 \mathrm{mM}$ pyrophosphate and 100 $\mathrm{mM}$ tetraborate (—-

enzyme have approximately identical values of both $\mathrm{K}_{\mathrm{m}}$ 's and $\mathrm{k}_{\mathrm{cat}}$ 's. Changing $\mathrm{pH}$ from 9.3 to 8.0 increases $\mathrm{k}_{\text {cat }}$ for the dissolved enzyme about three-fold while the $k_{\text {cat }}$ of the enzyme crystal decreases slightly. For the dissolved enzyme the $K_{m}$ is doubled while it is unchanged for the crystals.

Table II

Kinetic constants for hydrolysis of TAME by subtilisin Carlsberg

\begin{tabular}{l|c|c|c|c}
\hline & $\mathrm{pH}$ & $\begin{array}{c}\mathrm{K}_{\mathrm{m}} \\
\mathrm{mM}\end{array}$ & $\begin{array}{c}\mathrm{k}_{\mathrm{cat}} \\
\mathrm{sec}^{-1}\end{array}$ & $\begin{array}{c}\mathrm{k}_{\mathrm{cat}} / \mathrm{K}_{\mathrm{m}} \\
\mathrm{sec}^{-1} \mathrm{mM}^{-1}\end{array}$ \\
\hline Dissolved enzyme & 9.3 & 17 & 41 & 2.4 \\
crossed-linked crystals & 9.3 & 19 & 44 & 2.3 \\
dissolved enzyme & 8.0 & 42 & 136 & 3.2 \\
crossed-linked crystals & 8.0 & 19 & 30 & 1.55 \\
\hline
\end{tabular}

The experimental conditions corresponded to those described in the legend of Fig. 7, using $4 \mathrm{~mm}$-buffering capacity for the enzyme crystals. 


\subsubsection{The hydrolysis of casein}

In contrast to the hydrolysis of the low molecular weight substrates $\mathrm{NtCI}$ and TAME, where the rates with soluble and crystalline enzyme were of the same order of magnitude, the hydrolysis of the high molecular weight substrate casein by the crystalline enzyme was a very slow process, approx. $0.7 \%$ of the rate observed for the dissolved enzyme (Fig. 11). This suggested that the large casein molecules were only split by the enzyme molecules whose active sites were exposed to the bulk of the solution. A rough estimate of this number could be calculated from the dimensions of the long crystal rods. The cross-sections were approximately $1 \mu \mathrm{m}$ square and a monomolecular surface layer would be about $40 \dot{A}$ in thickness. Maximally one might expect that half of the active sites of the molecules in the surface layer point towards the bulk solution, and if all of

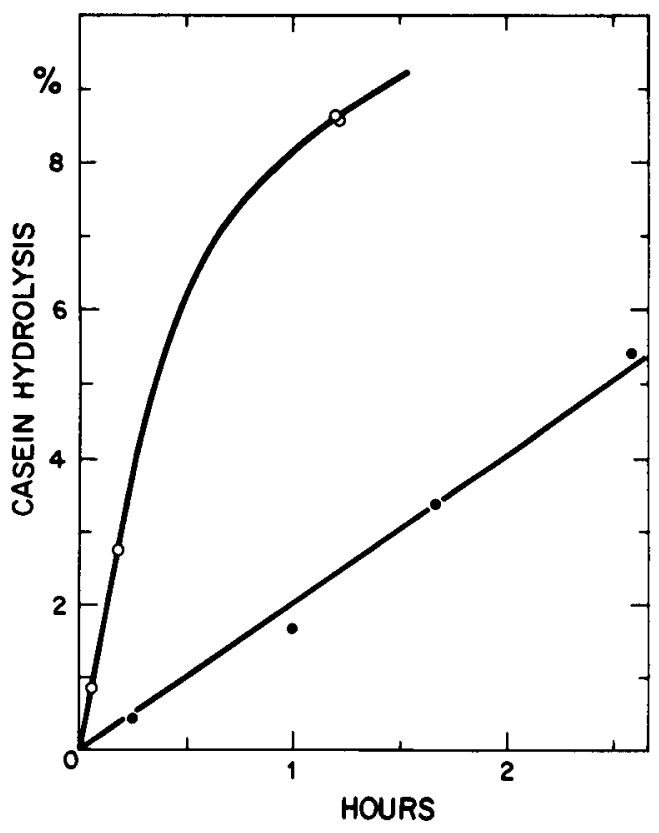

Figure 11 . The hydrolysis of $2 \%$ casein $\mathrm{pH} 8$ and $30^{\circ} \mathrm{C}$, by $57 \mu \mathrm{g} / \mathrm{ml}$ subtilisin crystals (- $\longrightarrow$ ) and 4 $\mu \mathrm{g} / \mathrm{ml}$ dissolved enzyme (- - - $)$. The concentration of crystalline enzyme was calculated from amino acid analysis and the concentration of dissolved enzyme from active site titration. The percentage of hydrolysis was estimated from concentrations of hydrolysis peptides determined from UV-absorption at $280 \mathrm{~nm}$ after precipitation of the protein with $10 \%$ trichloroacetic acid. these molecules were active we should expect an activity corresponding to $0.8 \%$ of the activity of the dissolved enzyme, in exellent agreement with the activity actually measured.

\section{DISCUSSION}

Cross-linked crystals of subtilisin Carlsberg were highly effective catalysts. The specific activities measured with TAME or $\mathrm{NtCI}$ as substrates were of similar magnitude as the activity of the enzyme in solution, and the packing of the molecules in the crystal so tight that it corresponded to a $30 \mathrm{~mm}$ concentration of active sites. The interlocking of the molecules in the crystal lattice had the effect that the enzyme molecules became unable to digest themselves such as would rapidly occur in solution. This prevention of autolysis permitted the subtilisin crystals to remain active at considerably higher temperatures than the dissolved enzyme, thus making it a practical possibility to use subtilisin at temperatures above $60^{\circ} \mathrm{C}$, i.e. in the temperature range of pasteurization where the risks of microbial infections are much lower.

The practical possibilities for the use of subtilisin in the form of cross-linked crystals are unfortunately limited by the fact that this form of the enzyme is effective only for the hydrolysis of the low molecular weight substrates which can diffuse freely through the crystal lattice. Casein was too large to penetrate into the enzyme crystals while the smaller substrates TAME and NtCI both diffused freely. Further experiments with substrates of different sizes are necessary to establish the maximum possible molecular size of substrates which can be used effectively with crystalline subtilisin.

It has been observed frequently that enzymes immobilized by covalent binding to insoluble carrier substances exhibit activities below those expected due to diffusional restrictions which decrease the concentrations of substrates inside the particles to lower values than in the surrounding solutions. $(6,8,9,12)$. In enzyme crystals the concentrations of catalytically active sites per unit volume are much higher than in matrix bound enzymes, and consequent- 
ly the risk of having limitations from diffusion effects would be expected to be higher in the enzyme crystals. However, practical experience indicates that it is sufficient to use small crystals to eliminate this problem. In the present report, subtilisin crystals smaller than $2 \mu \mathrm{m}$ in the shortest dimensions were found to be sufficiently small to eliminate diffusional effects when TAME and NtCI were used as substrates. This agrees with the observations of VALLEE and coworkers who found crystals of carboxypeptidases $A$ and $B$ to be without diffusion limitations when the crystals were 0.5 and 0.8 $\mu \mathrm{m}$, respectively, in the smallest dimensions $(1,20)$. With glycogen phosphorylase, KASVINSKY and MADSEN (11) found it even possible to use crystals as large at $10 \mu \mathrm{m}$ in the smallest dimension without any observable diffusion effects. Several theoretical estimates have been made of the maximal size an enzyme crystal may have before diffusional limitations interfere with the activity and normal kinetics. For the subtilisin crystals we used a treatment outlined by Sluyterman and De GraAF (19) where the maximal allowable crystal size (in the smallest dimension) is defined by

$\mathrm{d}_{\mathrm{c}}=\sqrt{\frac{\mathrm{K}_{\mathrm{m}} \cdot \mathrm{D}_{\mathrm{i}}}{\mathrm{k}_{\mathrm{cat}} \cdot[\mathrm{E}]}}$

where $D_{i}$ is the diffusion rate of the substrate and $[E]$ the enzyme concentration inside the crystal. Assuming that all of the enzyme molecules within the crystal are fully active, [E] is calculated to $30 \mathrm{~mm}$ based on the unit cell dimensions $77 \times 55 \times 53 \AA^{3}(15)$ with 4 enzyme molecules within this space. Very little is known about the actual values of $D_{i}$, the diffusion rate of the substrate inside the crystal, but using Sluyterman and DE GrafF's suggestion that these values are likely to be about 30 -fold lower than the values in water, we arrive at a value of approx. $0.3 \times 10^{-6} \mathrm{~cm}^{2} \mathrm{sec}^{-1}$ for $\mathrm{NtCl}$. Using these values and the values for $k_{\text {cat }}$ and $K_{m}$ from Table I for dissolved enzyme, equation [1] indicates the critical crystal size to be approx. $0.3 \mu \mathrm{m}$ in the smallest dimension. This size is considerably smaller than the crystals of $2 \mu \mathrm{m}$ we could use without detectable diffusion effects, indicating that the substrate diffuse more freely within the crystal than postulated, i.e. the internal diffusion coefficient was decreased by a factor of less than 30 relative to the diffusion in water. In their estimates of the diffusion coefficients for substrates within crystals of carboxypeptidases A and B, VALLEE and coworkers $(1,20)$ took into account only the steric hindrances arising from diffusion within the narrow pores of the crystal and thus arrived at figures about half of the diffusion rates in water. Treating diffusion within subtilisin crystals in the same manner we arrive at a critical size for the subtilisin crystals of approx. $1.2 \mu \mathrm{m}$ in better agreement with the experimental observations.

From Table I and II it is seen that the ratios of $\mathrm{K}_{\mathrm{m}} / \mathrm{k}_{\mathrm{cat}}$ to be used in equation [1] are slightly higher for TAME than for NtCI. On the other hand the higher molecular weight of TAME gives a slightly smaller diffusion coefficient. Thus, the critical crystal size is probably approximately identical for these substrates, consistent with the observation that both substrates could be used without complications from diffusional limitations.

Considering that molecules as large as TAME diffuse freely through the crystals, it is something of a paradox that the much smaller hydrogen ions liberated in the enzymatic hydrolysis of this substrate apparently accumulated within the crystal to such an extent that $\mathrm{pH}$ was decreased to a lower value than in the surrounding solution. However, it should be remembered that the overall concentration of TAME was higher than $10^{-3} \mathrm{M}$ while the concentration of hydrogen ions only was $10^{-8} \mathrm{M}$. For this reason the concentration differences originating from the enzymatic reaction, which on a molar basis are relatively small, will have a far greater effect on the $\mathrm{pH}$ than on the degree of saturation of the active sites of the enzyme. The requirement for electroneutrality will also link the transport of hydrogen ions to the transport of counterions. The different buffer anions have different diffu sion coefficients, and this may explain why different buffers have different capacities tc normalize the low reaction rates caused by the accumulation of hydrogen ions.

The curvature of the LINEWEAVER-BURK plots in unbuffered solutions can be explainec 
as an effect of the inherent buffer capacity of the TAME solutions which at high substrate concentrations becomes sufficient to take over the transport of the hydrogen ions being generated, and thus increase the reaction rates to the values observed at high buffer concentrations. At $\mathrm{pH}$ above 9 water alone had sufficient buffering capacity to prevent $\mathrm{pH}$ decreases in the crystals and curvatures of the Lineweaver-Burk plots were not observed.

Even when all diffusion effects are eliminated, minor variations between kinetic parameters for the dissolved and the crystalline forms of an enzyme might be expected from microenvironmental and partitioning effects (8). In subtilisin crystals the presence of some microenvironmental effects from the crosslinks were demonstrated from the small variations of the activities using TAME and the kinetic parameters using $\mathrm{NtCI}$ employing crystals cross-linked to different degrees.

Partitioning effects due to electrostatic or hydrophobic interactions between the substrates and the molecules in the crystal might displace the equilibrium concentrations of the substrates inside the crystals to values different from the concentrations in solutions. Such effects can hardly be eliminated completely and could very well be responsible for the relatively small differences which we observed between the kinetic parameters for dissolved and crystalline subtilisin Carlsberg.

The well-defined pictures of protein structures, which can be derived from X-ray crystallographic evidence, are now generally accepted as representing the time-average of a large number of closely related molecular conformations (21). On changing a protein from solution state to crystalline state new intermolecular interaction forces are introduced from the packing of the molecules in the crystal lattice. Thus, it becomes understandable that the molecular conformations which make the best fitting in the crystal lattice, i.e. those which have the lowest solubility, may well represent a time-average conformation different from the one in the solution state. Such conformational differences are actually observed, when both carboxypeptidases $A$ and $B(19,1)$ and phosphorylases a and $b$ (11) are crystallized.
Proteins which have a higher degree of conformational stability would be more likely to have identical conformations in different physical states. Subtilisin is an example of such a protein which both exhibits high stability against denaturing solvents (13) and have very low hydrogen isotope exchange rates (10). The present report confirms our expectations that this protein appears to have identical conformations in solution and in crystalline state. However, our measurements only reflect those aspects of the conformation of subtilisin which influence the kinetic properties of this enzyme and other methods would have to be applied to detect the possible presence of conformational differences in other parts of this molecule.

\section{ACKNOWLEDGEMENTS}

The authors wish to thank professor B. L. VALLEE for stimulating discussions and critical reading of the manuscript.

The valuable assistance of Mrs. BoDIL CORNELIUSSEN with the performance of the amino acid analyses is aknowledged.

\section{REFERENCES}

1. Alter, G. M., D. L. Leussing, H. Neurath \& B. L. VALLEE: Kinetic properties of carboxypeptidase $\mathrm{B}$ in solutions and crystals. Biochemistry. 16 , in press (1977)

2. BAYNE, S. J.\& M. OtTESEN: An overhead cuvette stirrer for studying enzymes attached to microgranular matrices. Carlsberg Res. Commun. 41, 345-348 (1976)

3. Bender, M. L., M. L. Begue-Cantón, R. L. Blakely, L. J. Brubacher, J. Feder, C. R. Gunter, F. J. Kezdy, J. V. KillhefFer, JR., T. H. Marshall, C. G. Miller, R. W. Roeske \& J. K. STOOPS: The determination of the concentration of hydrolytic enzyme solutions: $\alpha$-chymotrypsin, trypsin, papain, elastase, subtilisin and acetylcholinesterase. J. Am. Chem. Soc. 88, 58905913 (1966)

4. Blauer, G., D. Harmatz, E. Meir, M. K. SWENSSON \& B. ZVILICHOVSKY: The interaction of glutaraldehyde with poly ( $a, \mathrm{~L}$-lysine) $\mathrm{n}$-butylamine and collagen. I. The primary proton release in aqueous medium. Biopolymers. 14, 2585-2598 (1975) 
5. Cleland, W. W.: The statistic analysis of enzyme kinetic data. Adv. in Enzymology. 29, 1-32 (1967)

6. Engasser, J.-M. \& C. Horvath: Effect of internal diffusion in heterogeneous enzyme systems: Evaluation of true kinetic parameters and substrate diffusivity. J. Theor. Biol. 42, 137 155 (1973)

7. Engasser, J.-M. \& C. Horvath: Bufferfacilitated proton transport $\mathrm{pH}$ profile of bound enzymes. Biochim. Biophys. Acta. 358, 178-192 (1974)

8. Goldstein, L.: Kinetic behaviour of immobilized enzyme systems. In: Methods in Enzymology, Immobilized Enzymes. K. Mosbach ed. Academic Press. XLIV, 397-443 (1976)

9. Hovarth, C. \& J.-M. Engasser: External and internal diffusion in heterogeneous enzyme systems. Biotechn. and Bioeng. XVI, 909-923 (1974)

10. Johansen, J. T. \& M. Ottesen: Hydrogendeuterium exchange of subtilisin type Carlsberg and subtilisin type Novo. Israel Journal of Chemistry. 12, 339-349 (1974)

11. Kasvinsky, P. J. \& N. B. Madsen: Activity of glycogen phosphorylase in the crystalline state. J. Biol. Chem. 251, 6852-6859 (1976)

12. Laidler, K. J. \& P. S. Bunting: The chemical kinetics of enzyme action. 2nd ed. Oxford University Press ed. Clarendon Press, Oxford England (1973)

13. Ottesen, M., J. T. Johansen \& I. SVEndsen: Subtilisin: Stability properties and secondary binding sites. In: Structure-Function Relation- ships of Proteolytic Enzymes. P. Desnuelle, $H$. Neurath and $M$. Ottesen eds. Munksgaard, Copenhagen, Denmark. pp. 175-187 (1970)

14. Ottesen, M. \& I. Svendsen: The subtilisins. In: Methods in Enzymology, Proteolytic Enzymes. G. E. Perlmann and L. Lorand eds. Academic Press. XIX, 199-215 (1970)

15. Petsko, G. A. \& D. Tsernoglou: The structure of subtilopeptidase A. I. X-ray crystallographic data. J. Mol. Biol. 106, 453-456 (1976)

16. QUiocho, F. A. \& F. M. Richards: Intermolecular crosslinking of a protein in crystalline state: Carboxypeptidase A. Proc. Nat. Acad. Sci. 52, pp 833-839 (1964)

17. RupleY, J. A.: The comparison of protein structure in the crystal and in solution. In: Biological Macromolecules Series. Serge N. Timasheff and Gerald D. Fasman eds. Marcel Dekker Inc. Vol. II, pp 291-352 (1969)

18. Segel, I. H.: Enzyme kinetics. Behaviour and analysis of rapid equilibrium and steady state enzyme systems. Wiley-Interscience ed. John Wiley \& Sons (1974)

19. Sluyterman, L. A. Æ. \& M. J. M. De Graaf: The activity of papain in the crystalline state. Biochim. Biophys. Acta. 171, 277-287 (1969)

20. Spilburg, C. A., J. L. Bethune \& B. L. Vallee: Kinetic properties of crystalline enzymes. Carboxypeptidase A. Biochem. 16, 1142-1150 (1977)

21. WeBER, G.: Energetics of ligand binding to proteins. Adv. Prot. Chem. 29, 1-83 (1975) 